\title{
IJTMB at the 3.5-Year Mark: Aggregate Statistics on Journal Performance
}

\author{
Glenn M. Hymel, EdD, LMT \\ Senior Consulting Editor, IJTMB
}

Professor and Former Chair, Department of Psychological Sciences, Loyola University, New Orleans, LA, USA

KEYWORDS: massage research, massage education, massage practice, open access publishing, OJS, Google Analytics, journal webstats, journal statistics, aggregate statistics, performance metrics

Three previous IJTMB editorials ${ }^{(1-3)}$ have documented the Journal's progress from its inaugural issue in August 2008 to August 2011. In each of those earlier efforts, statistics were provided based primarily on journal performance in one-year time periods. As a reminder, the two major data sources were and still are (a) the IJTMB's Google Analytics web statistics site and (b) the Statistics sector of the Journal's own website.

This current editorial aggregates pertinent journal statistics across the IJTMB's 3.5-year history thus far that extends from August 2008 to February 2012. Such a composite consideration of the journal's activities and presumed impact should allow not only for a comprehensive retrospective, but also suggest a prospective view to guide future journal efforts.

Table 1 shows the aggregate statistics for only a pertinent subset of journal dimensions among several that are tracked by Google Analytics; viz., overview of site usage and visitors; international scope; new and returning visitors; and overview of traffic sources. Of particular note is the number of so-called unique visitors (i.e., unduplicated, counted-only-once, as in either "first time" or "prior" visitors specific to a selected date range; $\mathrm{n}=77,581$ ) considered against the backdrop of visits in toto $(\mathrm{n}=105,629)$. These data, when considered in tandem with the number of new visitors $(\mathrm{n}=77,398)$ vis-à-vis returning visitors $(\mathrm{n}=28,231)$, may reflect encouragingly on the initial appeal of the Journal yet questionably on the Journal's ability to sustain interest among those accessing the website. To assist in clarifying features of Table 1, Google Analytics provides an extensive Glossary as well as more detailed information regarding "Absolute Unique Visitors versus "New and Returning."

Indicative of the Journal's intended international focus are the 176 different countries/territories represented by colleagues and other interested parties who have accessed the IJTMB's website. This encouraging international range of exposure of the Journal would
TABLE 1. Aggregate Web Statistics from Google Analytics for the International Journal of Therapeutic Massage \& Bodywork Spanning the 3.5-Year Period from August 20, 2008-February 20, 2012

Dimensions $[n / n(\%)]$

Overview of Site Usage and Visitors

Visits (n)

105,629

Unique visitors $(n)$

77,581

Page views $(n)$

361,744

Average page views per visit ( $n$ )

3.42

International Scope

Countries/territories ( $n$ )

Visitors from top 10 countries/territories (n)

$\begin{array}{lc}\text { United States } & 57,726 \\ \text { Canada } & 14,841 \\ \text { United Kingdom } & 7,468 \\ \text { Australia } & 4,447 \\ \text { India } & 1,924 \\ \text { New Zealand } & 1,745 \\ \text { Germany } & 1,155 \\ \text { Poland } & 895 \\ \text { The Netherlands } & 868 \\ \text { The Philippines } & 852\end{array}$

New and Returning Visitors

$$
\begin{aligned}
& \text { New }[n(\%)] \\
& \text { Returning }[n(\%)]
\end{aligned}
$$

Overview of Traffic Sources

$$
\begin{aligned}
& \text { Search engines }[n(\%)] \\
& \text { Direct traffic }[n(\%)] \\
& \text { Referring sites }[n(\%)] \\
& \text { Other }[n(\%)]
\end{aligned}
$$

$41,832(39.60)$

$41,172(38.98)$

$22,526(21.33)$

$99(0.09)$ 
seem to suggest a diversity of contributing authors from various countries. To a certain extent that has, indeed, been the case in that 10 different countries are represented via journal entries thus far (viz., Australia, Belgium, Brazil, Canada, Germany, Italy, the Netherlands, New Zealand, Portugal, and the United States). Naturally, the IJTMB seeks to increase substantially the number of nations represented by contributing authors and encourages inquiries from anyone who may be considering a manuscript submission.

Tables 2 and 3 display the aggregate statistics compiled through the Open Journal Systems (OJS) software that was developed as part of Canada's Public Knowledge Project and that drives the various features of the Journal's website. The several dimensions as cited in Table 2 are obviously germane to the types of data typically tracked by professional/ academic journals, and address the principal features of the manuscript submission-through-reviewthrough-publication process.

Based on the aforementioned Statistics sector of the Journal's website and as shown in Table 2, the number of issues and items published through February 20, 2012, represents an average of six entries per journal issue. Considering the reality of six sections compromising the IJTMB-viz., Editorial,

Table 2. Aggregate Statistics from Canada's Public Knowledge Project's Open Journal Systems (OJS) for the International Journal of Therapeutic Massage \& Bodywork Spanning the 3.5-Year Period from August 20, 2008-February 20, 2012*

\begin{tabular}{lc}
\hline \multicolumn{1}{c}{ Dimensions } & {$[n / n(\%) / M]$} \\
\hline Issues published $(n)$ & 14 \\
Items published $(n)$ & 82 \\
Total submissions $(n)$ & 147 \\
Peer reviewed $(n)$ & 114 \\
Accepted $(n(\%))$ & $91(80)$ \\
Declined $(n(\%))$ & $23(20)$ \\
Resubmitted $(n(\%))$ & $15(13)$ \\
Days to review $(M)$ & 35 \\
Days to publication $(M)$ & 61 \\
Registered users $(n)$ & 9,672 \\
Registered readers $(n)$ & 9,589 \\
Article view counts $(n)$ & 243,654 \\
\hline
\end{tabular}

*The aggregate statistics here are based on the following number of issues of the journal per year: 2 in 2008; 4 in each of 2009, 2010, and 2011; and 0 in 2012 as of February 20, although preparatory features pertaining to the March 2012 issue are indeed represented.

$\dagger$ Percentages for peer reviewed submissions may not add up to $100 \%$, as items resubmitted are either accepted, declined, or still in process.
Research, Education, Practice, Commentary, and News/Announcements - this limited extent of content covered per issue is certainly not consistent with the Journal's ongoing objective of approximately 9-12 entries per issue. Contributing to this fact, undoubtedly, is the total number of submissions equaling 147, for an average of 11 submissions (or potentially publishable items) per issue thus far. The data pertaining to number of peer reviewed items and subsequent decisions to accept, decline, or resubmit are encouraging when considered in the context of days to review and days to publication averages of 35 and 61, respectively. On the average, then, manuscript submissions are being reviewed in a timely manner with subsequent publication within a two-month time frame. The categories of registered users and readers are each approaching the 10,000 mark, although a context for interpreting these data in a meaningful way has yet to be identified given the 3.5 years since the Journal's inaugural issue. The dimension labeled article view counts cites 243,654 hits across the 82 items published, with $39 \%$ of those hits (i.e., 95,149) accounted for by only the top 10 articles eliciting readers' attention.

Although earlier versions were presented in aggregate form via the September 2010 and 2011 editorials $^{(2-3)}$, an updated rendition of the 10 most frequently

TABLE 3. Ten Most Frequently Viewed IJTMB Articles Spanning the 3.5-Year Period from August 20, 2008-February 20, 2012

- "Orthopedic Massage Protocol for Post-Anterior Cruciate Ligament Reconstruction Patellofemoral Pain Syndrome: A Case Report" by Zalta (26,171 views)

- "The Architecture of the Connective Tissue in the Musculoskeletal System-An Often Overlooked Functional Parameter As to Proprioception in the Locomotor Apparatus" by Van der Wal (12,619 views)

- "Understanding the Process of Fascial Unwinding" by Minasny (11,015 views)

- "Fascia Research II: Second International Fascia Research Congress" by Findley (7,708 views)

- "Steps Toward Massage Therapy Guidelines: A First Report to the Profession" by Grant et al. (7,672 views)

- "Clinical Reasoning in Massage Therapy" by LeMoon (7,629 views)

- "Value of Qualitative Research in the Study of Massage Therapy" by Kania et al. (6,173 views)

- "The Integrated Taxonomy of Health Care: Classifying Both Complementary \& Biomedical Practices Using a Uniform Classification Protocol" by Porcino and MacDougall $(5,961$ views)

- "Directions \& Dilemmas in Massage Therapy Research: A Workshop Report from the 2009 North American Research Conference on Complementary and Integrative Medicine" by Moyer et al. $(5,132)$

- "The Effects of Massage Therapy on Pain Management in the Acute Care Setting" by Adams et al. (5,069 views) 
viewed IJTMB articles appears in Table 3. Still garnering by far the largest number of views with a count of 26,171 is the article by $\underline{Z a l t a}^{(4)}$ that originally (i.e., pre-publication) merited the Massage Therapy Foundation's 2007 Practitioner Case Report Gold Award. And still maintaining an approximately similar rank ordering as before-with the addition of one new entry - are the following articles (and corresponding topics) spanning a range of "hits" extending from 12,619 to 5,069 views: Van der $\mathrm{Wal}^{(5)}$, Minasny ${ }^{(6)}$, and Findley ${ }^{(7)}$ _fascia research specific; Grant et al. (8)-massage therapy guidelines; LeMoon $^{\left({ }^{(9)}-\text { clini- }\right.}$ cal reasoning; Kania et al. ${ }^{(10)}$ _ qualitative research in massage; Porcino and MacDougall ${ }^{(11)}$ __integrated taxonomy of healthcare; Moyer et al. ${ }^{(12)}$ _-workshop report from complementary and integrative medicine research conference; and Adams et al. ${ }^{(13)}$ _ pain management. Considerations admittedly not factored into this listing, yet undoubtedly influencing the number of hits registered, are variables such as (a) length of time since publication, (b) originating context of an article such as a research competition or a conference presentation, (c) principal intended audiences/ readership, and (d) ancillary communications with specifically-targeted audiences/readership in mind.

The three earlier editorials cited at the outset ${ }^{(1-3)}$ provide a 2008 to 2011 year-over-year comparison for assessing the Journal's progress. The aggregate statistics presented in Tables $1-3$ of this current editorial are likewise only descriptive in nature and represent what might be thought of as simply a "state of the journal" compilation. Among the several implications of these aggregate statistics as presented-some of which have been alluded to in the preceding discussion - are the following that might be deemed most pressing: (a) The retention of visitors beyond their initial visit to the journal needs to be increased beyond the current $27 \%$ of total visits represented by past returning visitors; (b) Of the 176 countries/territories represented by colleagues and others accessing the Journal, an increase in contributing authors beyond the 10 countries now represented would certainly advance the international intent of the journal; (c) An increase in the average number of manuscript submissions per journal issue is obviously prerequisite to approaching the desired average number of 9-12 published entries per issue; (d) With respect to article view count statistics, 10 of the 82 items published (12\%) account for 92,149 of the total 243,654 hits registered (39\%). Insights gleaned from pre- and post-publication circumstances surrounding these most frequently-accessed articles may suggest future strategies for encouraging published entries that attract and sustain an ever-increasing readership.

Thus far, the analyses provided reflect only yearover-year comparisons spanning three years and aggregate statistics at the current 3.5-year mark. Future efforts to track the IJTMB's development and impact, however, would be considerably enhanced by the addition of still-to-be-determined resources and analyses allowing for a comparison of the IJTMB with similar journals that are peer-reviewed and open access in nature. One possible starting point - though admittedly quite ambitious - might be that of investigating aggregate statistics specific to a subset of comparable journals listed among the 789 publications in the Health Sciences Sector of the Directory of Open Access Journals. A second possibility that is maybe even more challenging, yet perhaps more appropriate by virtue of the parallel nature of the statistics provided, would be a consideration of the Public Knowledge Project's listing of journals in North America using the OJS software (specifically, $n=1,343$ journals). Additionally, an eventual third possible performance metric for the IJTMB must be that of the Thomson Reuters Impact Factor. At the risk of over-simplification, the annual impact factor for a journal is a ratio between citations and recent citable items published. More specifically, it is the ratio between (a) the number of citations in a given year to articles published in the preceding two-year period, and (b) the number of articles published in that preceding two-year period.

With the two preceding paragraphs in mind, the bottom line is that variants of "within-journal" and "between-journal" analyses are critical to ensuring that the IJTMB's continued advancement is predicated on the best evidence that can be mustered. Future retrospectives on the Journal will indeed be enhanced if these combined and more robust analyses are incorporated.

\section{ACKNOWLEDGMENT}

The author acknowledges the insights provided by Antony Porcino, PhD (cand.), and Thomas W. Findley, $\mathrm{MD}, \mathrm{PhD}$, in preparing the final version of this editorial.

\section{CONFLICT OF INTEREST NOTIFICATION}

The author declares there are no conflicts of interest.

\section{COPYRIGHT}

Published under the CreativeCommons AttributionNonCommercial-NoDerivs 3.0 License.

\section{REFERENCES}

1. Hymel GM. International Journal of Therapeutic Massage and Bodywork: A first-year retrospective view reflecting Google Analytics and Open Journal Systems sources. Int J Ther Massage Bodyw. 2009;2(3):1-3. http://www.ijtmb.org/index.php/ ijtmb/article/view/60/69. Published September 23, 2009. Accessed February 28, 2012. 
2. Hymel GM. International Journal of Therapeutic Massage and Bodywork (IJTMB): A second-year retrospective reflecting Google Analytics and Open Journal Systems sources. Int J Ther Massage Bodyw. 2010;3(3):1-4. http://www.ijtmb.org/ index.php/ijtmb/article/view/107/124. Published September 28, 2010. Accessed February 28, 2012.

3. Hymel GM. International Journal of Therapeutic Massage and Bodywork (IJTMB): A third-year retrospective reflecting Google Analytics and Open Journal Systems sources. Int J Ther Massage Bodyw. 2011;4(3):1-5. http://www.ijtmb.org/index. php/ijtmb/article/view/150/175. Published September 30, 2011. Accessed February 28, 2012.

4. Zalta J. Massage therapy protocol for post-anterior cruciate ligament reconstruction patellofemoral pain syndrome: A case report. Int J Ther Massage Bodyw. 2008;1(2):11-21. http:// www.ijtmb.org/index.php/ijtmb/article/view/22/29. Published December 15, 2008. Accessed February 28, 2012.

5. Van der Wal J. The architecture of the connective tissue in the musculoskeletal system-An often overlooked functional parameter as to proprioception in the locomotor apparatus. Int $J$ Ther Massage Bodyw. 2009;2(4):9-23. http://www.ijtmb. org/index.php/ijtmb/article/view/62/79. Published December 7, 2009. Accessed February 28, 2012.

6. Minasny B. Understanding the process of fascial unwinding. Int J Ther Massage Bodyw. 2009;2(3):10-17. http://www.ijtmb. org/index.php/ijtmb/article/view/43/68. Published September 23, 2009. Accessed February 28, 2012.

7. Findley T. Fascia research II: Second international fascia research congress. Int J Ther Massage Bodyw. 2009;2(3):4-9. http://www.ijtmb.org/index.php/ijtmb/article/view/61/70. Published September 23, 2009. Accessed February 28, 2012.
8. Grant KE, Balletto J, Gowan-Moody D., et al. Steps toward massage therapy guidelines: A first report to the profession. Int J Ther Massage Bodyw. 2008;1(1):19-36. http://www.ijtmb. org/index.php/ijtmb/article/view/5/17. Published August 20, 2008. Accessed February 28, 2012.

9. LeMoon K. Clinical reasoning in massage therapy. Int $J$ Ther Massage Bodyw. 2008;1(1):12-18. http://www.ijtmb.org/ index.php/ijtmb/article/view/2/3. Published August 20, 2008. Accessed February 28, 2012.

10. Kania A, Porcino A, Vehoef MJ. Value of qualitative research in the study of massage therapy. Int J Ther Massage Bodyw. 2008;1(2):6-10. http://www.ijtmb.org/index.php/ijtmb/article/ view/26/33. Published December 15, 2008. Accessed February 28, 2012.

11. Porcino A, MacDougall, C. The integrated taxonomy of health care: Classifying both complementary and biomedical practices using a uniform classification protocol. Int $J$ Ther Massage Bodyw. 2009;2(3):18-29. http://www.ijtmb.org/index.php/ ijtmb/article/view/40/71. Published September 23, 2009. Accessed February 28, 2012.

12. Moyer CA, Dryden T, Shipwright S. Directions and dilemmas in massage therapy research: A workshop report from the 2009 North American Research Conference on Complementary and Integrative Medicine. Int J Ther Massage Bodyw. 2009;2(2):1527. http://www.ijtmb.org/index.php/ijtmb/article/view/51/64. Published June 29, 2009. Accessed February 28, 2012.

13. Adams R, White B, Beckett C. The effects of massage therapy on pain management in the acute care setting. Int J Ther Massage Bodyw. 2010;3(1):4-11. http://www.ijtmb.org/index.php/ ijtmb/article/view/54/96. Published March 17, 2010. Accessed February 28, 2012. 